\title{
Back Labor
}

National Cancer Institute

\section{Source}

National Cancer Institute. Back Labor. NCI Thesaurus. Code C92739.

A type of labor where the labor pain or discomfort is felt by the pregnant mother in her back. 